\title{
Neuregulin expression in solid tumors: Prognostic value and predictive role to anti-HER3 therapies
}

\author{
Alberto Ocaña ${ }^{1}$, Laura Díez-González ${ }^{1}$, Azucena Esparís-Ogando ${ }^{3,4}$, Juan Carlos \\ Montero ${ }^{3}$, Eitan Amir ${ }^{2}$, Atanasio Pandiella ${ }^{3}$ \\ ${ }^{1}$ Translational Research Unit, Albacete University Hospital, Albacete, Spain \\ ${ }^{2}$ Division of Medical Oncology and Hematology, Princess Margaret Cancer Centre, University of Toronto, Toronto, Canada \\ ${ }^{3}$ Cancer Research Center (CIC-IBMCC), CSIC-University of Salamanca, Salamanca, Spain \\ ${ }^{4}$ IBSAL, Salamanca, Spain
}

Correspondence to: Alberto Ocaña, e-mail: albertoo@sescam.jccm.es

Keywords: neuregulin, anti-HER3, prognostic value, predictive role

Received: February 20, $2016 \quad$ Accepted: March 28, 2016

Published: April 08, 2016

\section{ABSTRACT}

Background: Neuregulins (NRG) are a family of epidermal growth factor ligands which act through binding to HER3 and HER4 receptors. NRGs are widely expressed in solid tumors. Their prognostic significance or their role as predictors of benefit from anti-HER3 therapy is not known.

Results: Of 29 included studies, 7 studies reported the association between NRG and outcome. NRG was most commonly expressed in breast, prostate, colon and bladder cancers. NRG expression was not associated with either OS or PFS (HR: 3.47, 95\% CI 0.78-15.47, $p=0.10$ and HR: $1.64,95 \%$ CI 0.94-2.86, $p=0.08$, respectively). In 4 placebo controlled trials of anti-HER3 therapy, the addition of anti-HER3 antibodies to control therapy in unselected patients was not associated with improved PFS (HR: $0.88,95 \%$ CI 0.75-1.04. $p=0.14$ ). However, in patients with high NRG expression, there was significantly delayed progression (HR: $0.35,95 \% \mathrm{CI} 0.23-0.52, p<0.001$ ). Anti-HER3 antibodies were associated with increased risk of diarrhea, nausea and rash.

Methods: A search of electronically available databases identified studies exploring clinical outcomes based on NRG expression, as well as placebo-controlled trials of HER3directed therapy reporting results based on NRG expression status. Data were combined in a meta-analysis using generic inverse variance and random effects modeling for studies reporting the hazard ratio (HR) for overall (OS) or progression-free survival (PFS). Mantel-Haenszel random-effect modeling was used for odds ratio (OR) for 3-year and 5-year OS and PFS.

Conclusions: NRG expression is not associated with either OS or PFS, but is a predictor of benefit from anti-HER3 antibodies.

\section{INTRODUCTION}

Neuregulins or Heregulins (NRG) are a family of the Epidermal Growth Factor (EGF) ligands that are widely expressed in solid tumors [1-3]. Four different genes named $N R G-1, N R G-2, N R G-3$ and $N R G-4$ code for more than to 32 different NRG isoforms [2]. The NRGs act by binding to the ErbB/HER family of receptor tyrosine kinases. Four different ErbB/HER receptors have been described in mammals: ErbB1/HER1/EGFR, ErbB2/ HER2/neu, ErbB3/HER3 and ErbB4/HER4 [4, 5]. HER3 is the major NRG receptor [3,5-7].
ErbB/HER receptors and their ligands have been widely studied in cancer and linked to oncogenic transformation [4]. They have also been the target for directed therapies, including monoclonal antibodies such as trastuzumab or pertuzumab against HER2, or cetuximab against EGFR; or tyrosine kinase inhibitors such as lapatinib against EGFR and HER2 [8]. Of note, therapeutic inhibition of these receptors has been linked to clinical antitumor activity confirming the oncogenic role of these receptors in cancer [8]. HER3 expression has been associated with worse clinical outcome, and agents trying to neutralize its activity are in clinical 
development [9]. The fact that NRGs are the main activating ligands of HER3 suggests that tumors with high levels of NRG could be those that respond better to anti-HER3 therapies $[10,11]$.

In the current article we evaluated the expression and prognostic role of NRGs in solid tumors using publicly available data. We also studied the association of the expression of NRGs with clinical response to anti-HER3 antibodies. Finally we explored the toxicity associated with these anti-HER3 antibodies.

\section{RESULTS}

\section{Expression of NRG in solid tumors}

A total of 29 studies reported data on expression of NRG in solid tumors [12-40]. Characteristics of included studies are shown in Table 1 . NRG was more studied in breast cancer ( 9 studies) and prostate cancer ( 4 studies) followed by colon and bladder cancer ( 3 studies for each tumor).

\section{Association of NRG with clinical outcome}

A total of eleven studies reported the association between NRG and outcome. Seven were included in the analyses for the specific follow-up time points. Of these, six studies reported data on OS [14, 20, 24, 30, 32, 37] and six studies reported data on intermediate endpoints such as PFS or time to relapse [20, 24, 25, 30, 32, 37]. Figure 1 shows the flow chart for the selection of studies.

\section{Overall survival}

When all studies were pooled, there was no apparent association between NRG and OS (OR for 5 year OS: $1.01,95 \%$ CI $0.45-2.28, p=0.98$, Figure $2 \mathrm{~A}$ ). There was significant heterogeneity (Cochran Q $p=0.03, I^{2}=63 \%$ ) with one study in prostate cancer [37] showing an association with improved outcomes while the remaining individual studies showed no significant association. Exclusion of the outlying study did not change the results significantly (OR for 5 year OS: $1.30,95 \%$ CI $0.78-2.14$, $p=0.31)$. Similar results were observed in the two studies $[24,32]$ that reported HR for OS (pooled HR: 3.47, 95\% CI $0.78-15.47, p=0.10$, Figure $2 \mathrm{~B}$ ) and when OS was examined at 3 years (pooled OR: $1.25,95 \%$ CI $0.80-1.95$, $p=0.33)$.

\section{Progression-free survival}

When all studies were pooled, there was no apparent association between NRG and PFS (OR for 5 year PFS: 1.97, 95\% CI 0.58-6.68, $p=0.27$, Figure 3A). Once again, there was significant heterogeneity (Cochran Q $p<0.001, I^{2}=82 \%$ ), although for PFS caused by general heterogeneity and not individual outlying studies. Similar results were observed in the two studies $[24,32]$ that reported HR for PFS (pooled HR: 1.64, 95\% CI $0.94-$ $2.86, p=0.08$, Figure 3B) and when PFS was examined at 3 years (pooled OR: $2.17,95 \%$ CI $0.76-6.21, p=0.15$ ).

\section{NRG and benefit from anti-HER3 therapies}

Next we aimed to explore if the expression of $\mathrm{NRG}$ was a predictor of benefit from therapy with anti-HER3 antibodies. To do so, we pooled the HR for PFS among four randomized trials [41-44] (Table 2). Results showed that in patients unselected for NRG, anti-HER3 antibodies were not associated with improved PFS (pooled HR: 0.88, $95 \%$ CI 0.75-1.04. $p=0.14$, Figure 4A). However, among patients with NRG expression, there was significantly delayed progression (pooled HR: $0.35,95 \% \mathrm{CI} 0.23-0.52$, $p<0.001$, Figure 4B).

\section{Toxicity of anti-HER3 therapies}

Anti-HER3 antibodies were associated with significantly increased odds of diarrhea, nausea and vomiting, and rash as shown in Table 3.

\section{Evaluation of NRG expression}

Finally, we analyzed the different approaches used to evaluate the expression of NRG in solid tumors. In our retrospective analyses we observed that in the majority of studies the methods used were immunohistochemical assessment or polymerase chain reaction (PCR). Of note in those clinical studies in which the expression of NRG was used as a biomarker to select responsive patients, NRG was evaluated exclusively using mRNA by PCR (Table 2).

\section{DISCUSSION}

In the present article we describe the prognostic role of NRG expression, and the predictive accuracy of $\mathrm{NRG}$ expression as a biomarker of benefit from antiHER3 therapies. With respect to the first aspect, no clear association was found between NRG expression and clinical outcome when analyzing all the studies globally. However, patients with tumors that expressed high levels of NRG had significantly delayed progression of the disease when treated with anti-HER3 antibodies, compared with those without such expression.

Through binding to ErbB/HER receptors, particularly HER3, the NRGs control several biological responses linked to the malignant phenotype, including proliferation or metastatic dissemination $[15,45]$. In this context, it was expected that tumors with high expression of this ligand were associated with poor outcome. In fact, for some tumor subtypes such as breast cancer, expression of specific isoforms of NRG have been linked with worse outcome [46]. However, when analyzing the overall relevance of NRG expression in several tumor types, this 
Table 1: Characteristics on included studies

\begin{tabular}{|c|c|c|c|c|c|}
\hline Type of tumor & & ID & NRG & Assay & Estimate of expression (sample size) \\
\hline \multirow[t]{3}{*}{ Bladder cancer } & & $\begin{array}{l}\text { Forster } 2011 \\
{[12]}\end{array}$ & $\begin{array}{l}\text { NRG1 } \alpha, \text { and } \\
\text { NRG1 } \beta\end{array}$ & RT-PCR & Not described $(n=59)$ \\
\hline & & $\begin{array}{l}\text { Amsellem- } \\
\text { Ouazana } 2006 \\
{[13]}\end{array}$ & $\begin{array}{l}\text { NRG1, NRG2 } \\
\text { and NRG3 }\end{array}$ & RT-PCR & Not described $(n=73)$ \\
\hline & & $\begin{array}{l}\text { Memon } 2004 \\
{[14]}\end{array}$ & $\begin{array}{l}\text { HRG1 } \alpha, \text { HRG1 } \beta, \\
\text { HRG2 } \alpha, \text { HRG2 } \beta, \\
\text { HRG3 and } \\
\text { HRG4 }\end{array}$ & RT-PCR & $\begin{array}{l}47 \% \text { HRG } 1 \alpha, 49 \% \text { HRG } 1 \beta, 53 \% \\
\text { HRG } 2 \alpha, 42 \% \text { HRG } 2 \beta, 49 \% \text { HRG3 } \\
\text { and } 34 \% \text { HRG4 }(n=88)\end{array}$ \\
\hline \multirow[t]{9}{*}{ Breast cancer } & Breast cancer & $\begin{array}{l}\text { Seoane } 2015 \\
{[16]}\end{array}$ & NRG & Inmunohistochemistry & $34 \%(n=76)$ \\
\hline & $\begin{array}{l}\text { HER2 negative breast } \\
\text { cancers }\end{array}$ & Haas 2009 [17] & HRG & Inmunohistochemistry & $26 \%(n=171)$ \\
\hline & Breast cancer & $\begin{array}{l}\text { de Alava } 2007 \\
{[18]}\end{array}$ & NRG & Inmunohistochemistry & $50 \%(n=151)$ \\
\hline & $\begin{array}{l}\text { Pre-invasive ductal } \\
\text { carcinoma in situ of the } \\
\text { breast (DCIS) }\end{array}$ & $\begin{array}{l}\text { Marshall } 2006 \\
{[19]}\end{array}$ & $\begin{array}{l}\text { HRG1 } \alpha, \text { HRG1 } \beta, \\
\text { HRG2 } \alpha, \text { HRG2 } \beta, \\
\text { NRG3 and } \\
\text { NRG4 }\end{array}$ & Inmunohistochemistry & $30-80 \%(n=60)$ \\
\hline & Breast cancer & $\begin{array}{l}\text { Dunn } 2004 \\
{[20]}\end{array}$ & $\begin{array}{l}\text { HRG1 } \alpha, \text { HRG1 } \beta, \\
\text { HRG2 } \alpha, \text { HRG2 } \beta, \\
\text { NRG3 and } \\
\text { NRG4 }\end{array}$ & Inmunohistochemistry & $35-45 \%(n=45)$ \\
\hline & $\begin{array}{l}\text { Locally advanced breast } \\
\text { cancer }\end{array}$ & Raj 2001 [21] & NRG1 & Inmunohistochemistry & $84 \%(n=115)$ \\
\hline & Primary Breast Cancer & \begin{tabular}{|l} 
Esteva 2001 \\
{$[22]$}
\end{tabular} & Heregulin & Inmunohistochemistry & $48 \%(n=35)$ \\
\hline & Breast cancer & \begin{tabular}{|l|} 
Visscher 1997 \\
{$[23]$}
\end{tabular} & HRG & Inmunohistochemistry & $38 \%(n=34)$ and $50 \%(n=34)^{*}$ \\
\hline & Breast cancer & \begin{tabular}{|l|} 
Normanno \\
$1995[26]$ \\
\end{tabular} & HRG & Western blotting & $25 \%(n=60)$ \\
\hline \multirow[t]{3}{*}{ Colon cancer } & Colorectal cancer & $\begin{array}{l}\text { Mitsui } 2014 \\
{[24]}\end{array}$ & HRG & Inmunohistochemistry & $\begin{array}{l}46 \%(n=155) \text { (cytoplasm of cancer } \\
\text { cells) }\end{array}$ \\
\hline & Colorectal cancer & $\begin{array}{l}\text { Boeck } 2012 \\
{[25]}\end{array}$ & $\begin{array}{l}\text { tNRG1 } \\
\text { (transmembrane } \\
\text { neuregulin 1) }\end{array}$ & Inmunohistochemistry & $76 \%(n=54)$ (stromal) \\
\hline & Colon cancer & $\begin{array}{l}\text { Venkateswarlu } \\
2002[26]\end{array}$ & Heregulin & Inmunohistochemistry & Not described \\
\hline $\begin{array}{l}\text { Endometrial } \\
\text { cancer }\end{array}$ & & $\begin{array}{l}\text { Srinivasan } \\
1999 \text { [37] }\end{array}$ & $\begin{array}{l}\text { NRG1 } \alpha \text { and } \\
\text { NRG1 } \beta\end{array}$ & Inmunohistochemistry & Not described $(n=41)$ \\
\hline $\begin{array}{l}\text { Gastrointestinal } \\
\text { malignant } \\
\text { lymphoma }\end{array}$ & $\begin{array}{l}7 \text { mucosa-associated } \\
\text { lymphoid tissue (MALT) } \\
\text { lymphomas, } 6 \text { follicular } \\
\text { lymphomas (FLs), } 2 \\
\text { mantle lymphomas, } \\
7 \text { diffuse large B cell } \\
\text { lymphomas (DLBCLs), } 1 \\
\text { T cell lymphoma and } \\
3 \text { Burkitt lymphomas }\end{array}$ & Ebi $2011[28]$ & NRG4 & Inmunohistochemistry & $48 \%(n=26)$ \\
\hline $\begin{array}{l}\text { Hepatocellular } \\
\text { carcinoma (HCC) }\end{array}$ & & $\begin{array}{l}\text { Hsieh } 2011 \\
{[29]}\end{array}$ & NRG1 & $\begin{array}{l}\text { Immunoblotting } \\
\text { analysis }\end{array}$ & $100 \%(n=9)$ \\
\hline $\begin{array}{l}\text { Lung } \\
\text { adenocarcinoma }\end{array}$ & & $\operatorname{Pan} 2015$ [30] & NRG1 & Inmunohistochemistry & $49 \%$ tumor, $10 \%$ stroma $(n=115)$ \\
\hline Medulloblastoma & & \begin{tabular}{|l} 
Gilbertson \\
$1998[31]$
\end{tabular} & NRG1 $\beta$ & Inmunohistochemistry & $87 \%(n=48)$ \\
\hline $\begin{array}{l}\text { Oropharyngeal } \\
\text { Squamous Cell } \\
\text { Carcinoma } \\
\text { (OPSCC) }\end{array}$ & & Qian 2015 [32] & HRG mRNA & In situ hybridization & $77 \%(n=96)$ \\
\hline
\end{tabular}




\begin{tabular}{|c|c|c|c|c|c|}
\hline Ovarian cancer & & \begin{tabular}{|l} 
Gilmour 2002 \\
{$[33]$}
\end{tabular} & $\begin{array}{l}\text { NRG1 } \alpha \text { and } \\
\text { NRG1 } \beta\end{array}$ & $\begin{array}{l}\text { Inmunohistochemistry } \\
\text { and RT-PCR }\end{array}$ & $\begin{array}{l}\text { Inmunohistochemistry: } 77 \% \text { NRG1 } \alpha \\
-87 \% \text { NRG1 } \beta(n=53) \text { and RT-PCR: } \\
83 \% \text { NRG }(n=24)\end{array}$ \\
\hline $\begin{array}{l}\text { Pancreatic ductal } \\
\text { adenocarcinoma } \\
\text { (PDAC) }\end{array}$ & & Kolb 2007 [34] & HRG & Inmunohistochemistry & $85 \%(n=14)$ \\
\hline $\begin{array}{l}\text { Papillary thyroid } \\
\text { cancer }\end{array}$ & & \begin{tabular}{|l} 
Fluge 2000 \\
{$[35]$}
\end{tabular} & HRG precursor & Inmunohistochemistry & $78-83 \%(n=134)$ \\
\hline \multirow[t]{4}{*}{ Prostate cancer } & Prostate cancer & \begin{tabular}{|l} 
Hayes 2011 \\
{$[36]$}
\end{tabular} & $\begin{array}{l}\text { NRG4 (anti- } \\
\text { 127: all NRG4 } \\
\text { isotypes, anti- } \\
\text { 123: NRG4 } \alpha 1 \\
\text { and NRG4 } 2 \text {, } \\
\text { anti-128: } \\
\text { NRG4 } 1 \text {, anti- } \\
\text { 135: NRG4 } \alpha 2 \text {, } \\
\text { anti-134: } \\
\text { NRG4 } \beta 3 \text { ) }\end{array}$ & Inmunohistochemistry & $\begin{array}{l}\text { Anti-123: weak }(40 \%), \text { moderate } \\
(45 \%) \text {, strong }(17.5 \%) \text {; Anti-127: weak } \\
(45 \%), \text { moderate }(0 \%) \text {, strong }(0 \%) ; \\
\text { Anti-128: weak }(38.5 \%) \text {, moderate } \\
(12.8 \%) \text {, strong }(2.5 \%) \text {; Anti- } 134: \\
\text { weak }(46.2 \%) \text {, moderate }(0 \%) \text {, strong } \\
(0 \%) \text {; Anti-135: weak }(23.7 \%), \\
\text { moderate }(7.9 \%) \text {, strong }(0 \%) \\
(n=40)\end{array}$ \\
\hline & Adenocarcinoma prostate & \begin{tabular}{|l} 
Grimsley 2010 \\
{$[37]$}
\end{tabular} & HRG & Inmunohistochemistry & $\begin{array}{l}\text { Cytoplasm 99\%, cell membrane } 46 \% \text {, } \\
\text { nucleus } 54 \%(n=45)\end{array}$ \\
\hline & Prostate cancer & Lyne 1997 [38] & & Inmunohistochemistry & $100 \%(n=24) *$ \\
\hline & $\begin{array}{l}18 \text { well, } 15 \text { moderately } \\
\text { and } 17 \text { poorly } \\
\text { differentiated }\end{array}$ & \begin{tabular}{|l} 
Leung 1997 \\
{$[39]$}
\end{tabular} & HRG $\alpha$ & Inmunohistochemistry & $72 \%(n=50)$ \\
\hline $\begin{array}{l}\text { Vestibular } \\
\text { schawannoma }\end{array}$ & & $\begin{array}{l}\text { Hansen } 2004 \\
{[40]}\end{array}$ & NRG & Inmunohistochemistry & $100 \%(n=8)$ \\
\hline
\end{tabular}

hypothesis was not verified suggesting that the role of NRG in cancer probably depends on other biological characteristics including tumor subtype. Moreover, since the actions of NRGs depend on the presence of their cognate receptors, the mere expression of NRGs may not be biologically fruitful unless expression of those receptors is present in the tumoral tissue. In fact, the link among patient outcome and expression of HER3

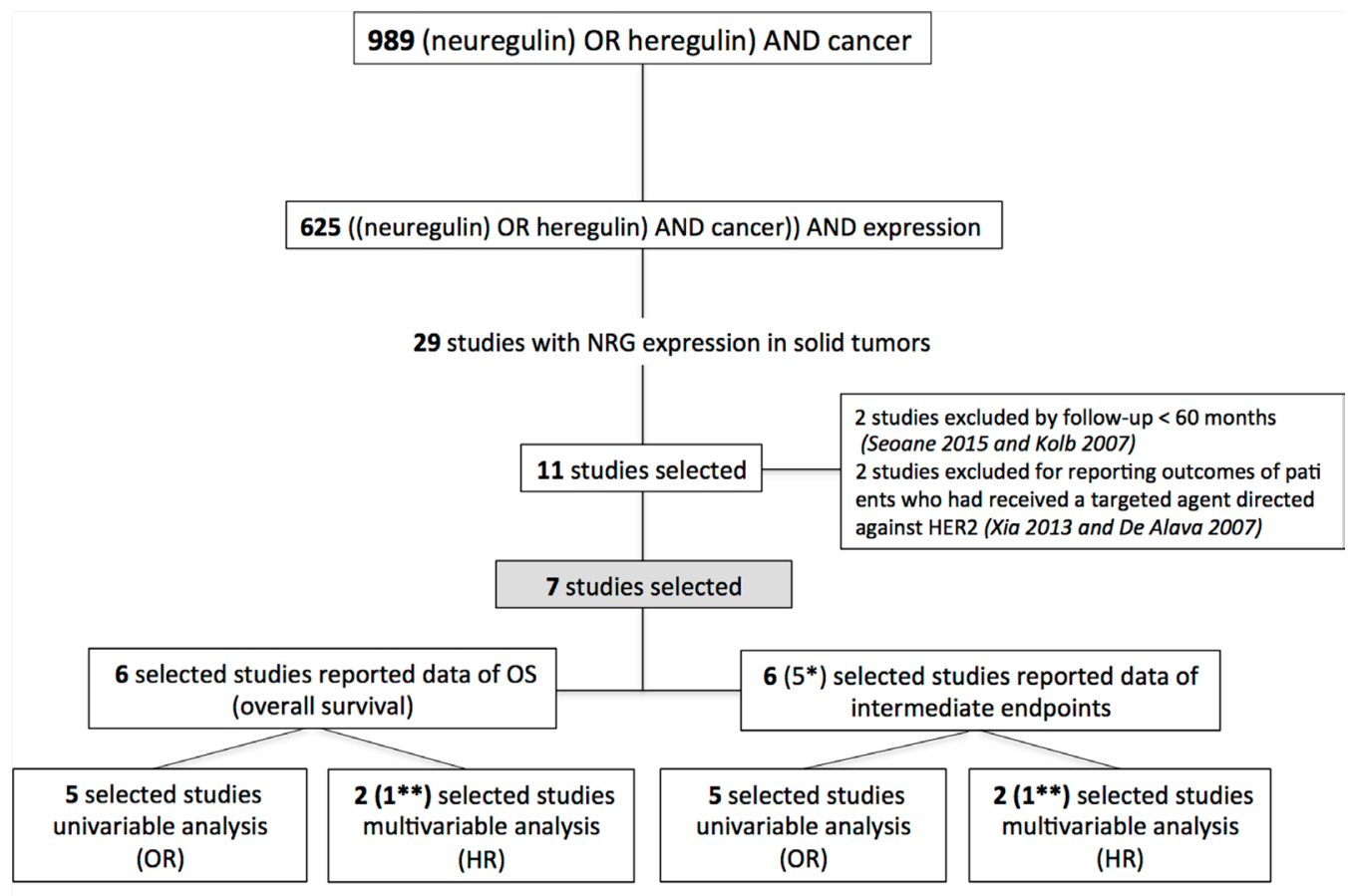

* OS and intermediate endpoints

** OR and $\mathrm{HR}$

Figure 1: Flow chart for the selection of studies. 
points in that direction. It is therefore likely that tumors expressing such receptor may be fed by NRGs produced by either the tumoral cells or their microenvironment. This biological situation may therefore be highly sensitive to agents, such as anti-HER3 antibodies, that disrupt the NRG-HER3 interaction and signaling axis. In line with this hypothesis is the fact that activation of HER3 by NRG in cellular models predicts response to anti-HER3 therapies or antibodies against HER2 [10, 17, 45]. This situation represented the basis for the selection of NRG as a biomarker of response to anti-HER3 strategies. Our pooled analyses validate results from individual studies,

A

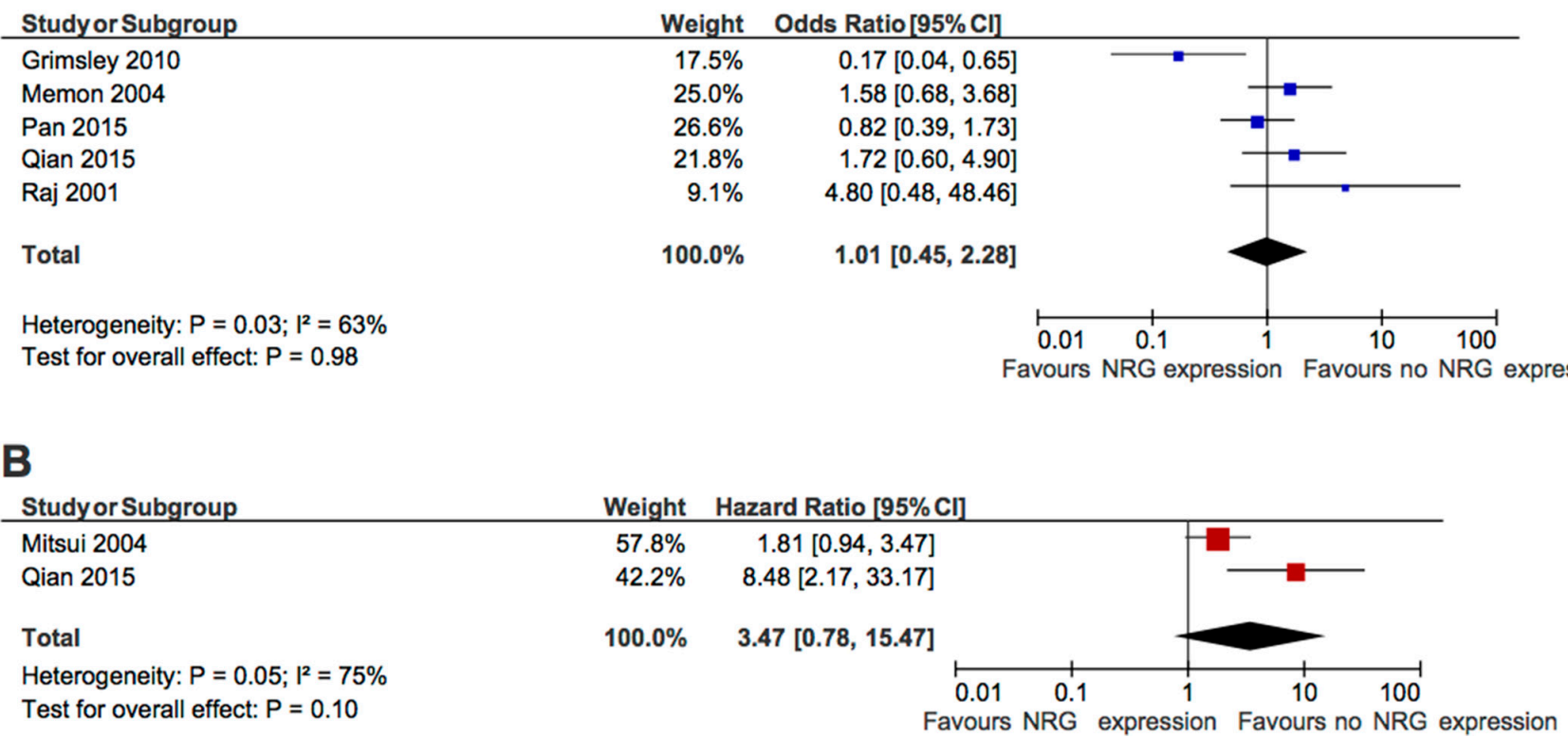

Figure 2: Forest plots showing association between NRG expression and overall survival. (A) Odd of survival at 5 years. (B) Hazard ratio for survival.

\section{A}

\begin{tabular}{lr} 
Studyor Subgroup & Weight \\
\hline de Boeck 2012 & $13.8 \%$ \\
Grimsley 2010 & $19.2 \%$ \\
Pan 2015 & $23.3 \%$ \\
Qian 2015 & $21.2 \%$ \\
Raj 2001 & $22.6 \%$ \\
Total & $100.0 \%$ \\
& \\
Heterogeneity: $P<0.001 ;\left.\right|^{2}=82 \%$ & \\
Test for overall effect: $P=0.28$ &
\end{tabular}

Odds Ratio [95\% $\mathrm{Cl}]$ $12.00[1.28,112.66]$

$0.40[0.10,1.63]$

$0.85[0.39,1.87]$

$1.35[0.44,4.12]$

$8.57[3.46,21.20]$

$00.0 \% \quad 1.97[0.58,6.68]$

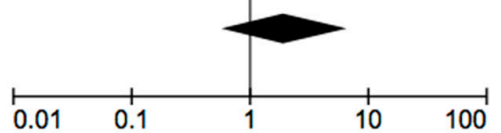

Favours NRG expression Favours no NRG expression

\section{B}

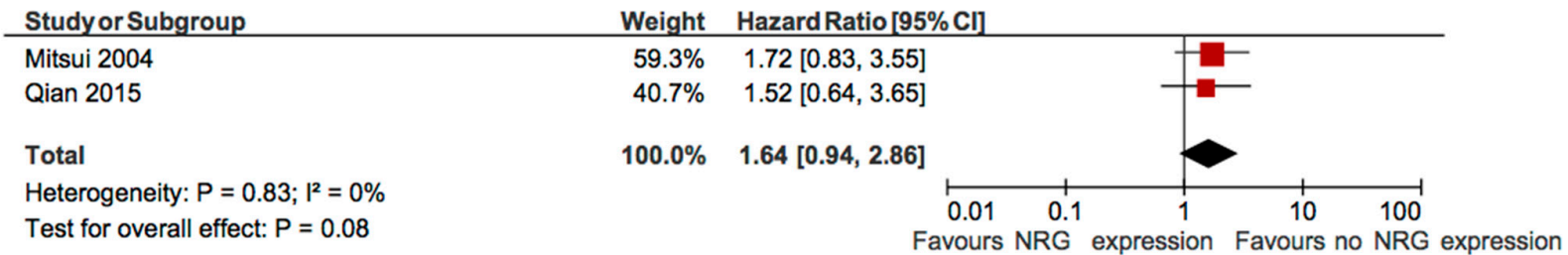

Figure 3: Forest plots showing association between NRG expression and progression-free survival. (A) Odd of freedom from progression at 5 years. (B) Hazard ratio for progression-free survival. 
Table 2: Characteristics of ongoing studies with anti-HER3 antibodies

\begin{tabular}{|c|c|c|c|c|c|}
\hline ID & Poster Title & Congress & Total (n) & Type tumor & Determination of NRG \\
\hline $\begin{array}{l}\text { Higgins } \\
2014[41]\end{array}$ & $\begin{array}{l}\text { A randomized, double- } \\
\text { blind phase II trial of } \\
\text { exemestane plus MM-121 } \\
\text { (a monoclonal antibody } \\
\text { targeting ErbB3) or } \\
\text { placebo in postmenopausal } \\
\text { women with locally } \\
\text { advanced or metastatic } \\
\text { ER+/PR }+ \text { HER2-negative } \\
\text { breast cancer }\end{array}$ & $\begin{array}{l}2014 \text { ASCO } \\
\text { Annual } \\
\text { Meeting }\end{array}$ & 115 & $\begin{array}{l}\text { Locally advanced } \\
\text { or metastatic } \\
\text { ER+/PR+, } \\
\text { HER2-negative } \\
\text { breast cancer }\end{array}$ & $\begin{array}{l}\text { BM+ patients were defined } \\
\text { as having: } \\
\text { - High HRG mRNA by RT- } \\
\text { PCR (score }>-5) \\
\text { - Low ErbB2 by qIHC } \\
\left(\log _{10} \text { ErbB2 }<5.1\right)\end{array}$ \\
\hline $\begin{array}{l}\text { Liu } 2014 \\
{[42]}\end{array}$ & $\begin{array}{l}\text { A phase II randomized } \\
\text { open-label study of } \\
\text { MM-121, a fully human } \\
\text { monoclonal antibody } \\
\text { targeting ErbB3, in } \\
\text { combination with weekly } \\
\text { paclitaxel versus weekly } \\
\text { paclitaxel in patients } \\
\text { with platinum-resistant/ } \\
\text { refractory ovarian cancers }\end{array}$ & $\begin{array}{l}2014 \text { ASCO } \\
\text { Annual } \\
\text { Meeting }\end{array}$ & 223 & $\begin{array}{l}\text { Platinum } \\
\text { resistant/ } \\
\text { refractory ovarian } \\
\text { cancers }\end{array}$ & $\begin{array}{l}\text { BM+ patients were defined } \\
\text { as having: } \\
\text { - Detectable HRG mRNA } \\
\text { by RNA-ISH } \\
\text { - } \log _{10} \text { ErbB } 2<5.1 \text { by } \\
\text { qIHC }\end{array}$ \\
\hline $\begin{array}{l}\text { Sequis } \\
2014[43]\end{array}$ & $\begin{array}{l}\text { A randomized phase } 2 \text { trial } \\
\text { of MM-121, a fully human } \\
\text { monoclonal antibody } \\
\text { targeting ErbB3, in } \\
\text { combination with erlotinib } \\
\text { in EGFR wild-type } \\
\text { NSCLC patients }\end{array}$ & $\begin{array}{l}2014 \text { ASCO } \\
\text { Annual } \\
\text { Meeting }\end{array}$ & 129 & $\begin{array}{l}\text { EGFR wide-type } \\
\text { NSCLC }\end{array}$ & $\begin{array}{l}\text { BM+ patients were defined } \\
\text { as having detectable HRG } \\
\text { mRNA by RNA-ISH }\end{array}$ \\
\hline $\begin{array}{l}\text { Von Pawel } \\
2014 \text { [44] }\end{array}$ & $\begin{array}{l}\text { Phase } 2 \text { HERALD study of } \\
\text { patritumab with erlotinib in } \\
\text { advanced NSCLC subjects }\end{array}$ & $\begin{array}{l}2014 \text { ASCO } \\
\text { Annual } \\
\text { Meeting }\end{array}$ & 141 & $\begin{array}{l}\text { Advanced } \\
\text { NSCLC (high } \\
\text { dose) ITT } \\
\text { population } \\
\text { (intent-to-treat) }\end{array}$ & $\begin{array}{l}\text { - A validated quantitative } \\
\text { polymerase chain reaction } \\
\text { assay was developed } \\
\text { to measure mRNA in } \\
\text { formalin-fixed paraffin- } \\
\text { embedded tissue. } \\
\text { - The HRG cutoff was set at } \\
\text { the median delta threshold } \\
\text { cycle }(\Delta \mathrm{Ct}) \text { based on } \\
\text { samples that were blinded } \\
\text { with respect to treatment } \\
\text { group and clinical } \\
\text { outcomes }\end{array}$ \\
\hline
\end{tabular}

confirming its potential use as a biomarker of benefit from therapies using anti-HER3 antibodies.

Use of NRG as a biomarker for the selection of patients that may benefit from therapies based on antiHER3 antibodies requires the development of a reliable test to measure NRG expression in tumoral samples. While in all ongoing studies testing anti-HER3 antibodies NRG has been evaluated by PCR, in the retrospective series this ligand was also studied using immunohistochemistry. A limitation of this approach is the existence of different isoforms of $\mathrm{NRG}$, so it is mandatory to establish the isoforms present in the samples to be analyzed using clinically-friendly methods for their identification and measurement. Finally, the optimal cut-offs for defining positive expression in different tumors also require standardization.

This study has limitations. It is a study based on published data, so it could have a potential bias for the identification of only positive published studies. Secondly, as mentioned, the methods for identification 
of NRG expression were variable with some studies using antibodies and others selecting patients based on the expression of NRG mRNA by PCR. Finally the combination of different tumour types adds heterogeneity which may mask a true effect in a specific tumour type. This is a major limitation of the actual study. It will be desirable to reevaluate the relevance of NRG expression in the different tumors when more studies will be available.

In conclusion, this study suggests that assessment of NRG expression, despite showing no significant prognostic association with OS or PFS, is a predictor of benefit from anti-HER3 antibodies.

\section{MATERIALS AND METHODS}

Preferred Reporting Items for Systematic Reviews and Meta-Analyses guidelines was used to guide this analyses [47].

\section{Data sources and study selection}

Medline (Host: PubMed) was searched for studies published between September 1995 and October 2015, which evaluated the expression of neuregulin/heregulin in solid tumors by immunohistochemistry (IHC) or quantitative real-time RT-PCR. Studies using other assays were excluded to maintain homogeneity. We used the MeSHterms "neuregulin" or "heregulin" and "cancer", adding the limitation of publications in English. Additional studies were identified through citation lists.

Two independent searches were conducted. First, we explored the association of NRG with clinical outcome. Eligible studies reported hazard ratios (HR) and 95\% confidence interval (CI) and/or $p$-value for overall survival (OS) from multivariable analyses; or provided Kaplan-Meier curves for OS at 3 and 5 years based on the expression of NRG. Studies reporting outcome of patients who had received a targeted agent directed against HER2 were excluded as well as studies not reported as a final publication. Data for OS were preferred but if not available, studies reporting data on intermediate endpoints such as progression-free survival (PFS) or time to relapse were included and analyzed separately. For the purpose of this analysis, PFS and time to relapse were considered to be interchangeable. Second, we explored if the expression of NRG was a predictor of benefit of treatment with antiHER3 antibodies. Eligible studies reported HR and 95\% $\mathrm{CI}$ and/or $p$-value for PFS from multivariable analyses in placebo-controlled randomized trials of anti-HER3 agents. In this cohort of studies we also explored toxicities of antiHER3 therapies.

A

\begin{tabular}{lr} 
Study or Subgroup & Weight \\
\hline Higgins 2014 & $14.4 \%$ \\
Liu 2014 & $26.4 \%$ \\
Sequist 2014 & $17.9 \%$ \\
Von Pawel 2014 & $41.2 \%$ \\
& \\
Total & $100.0 \%$ \\
Heterogeneity: $P=0.71 ; I^{2}=0 \%$ & \\
Test for overall effect: $Z=1.47(P=0.14)$ &
\end{tabular}

Weight Hazard Ratio [95\% Cl]

$14.4 \% \quad 0.77[0.50,1.20]$

$26.4 \% \quad 1.03[0.74,1.42]$

$17.9 \% \quad 0.81[0.54,1.20]$

$41.2 \% \quad 0.87[0.67,1.13]$

$100.0 \% \quad 0.88[0.75,1.04]$

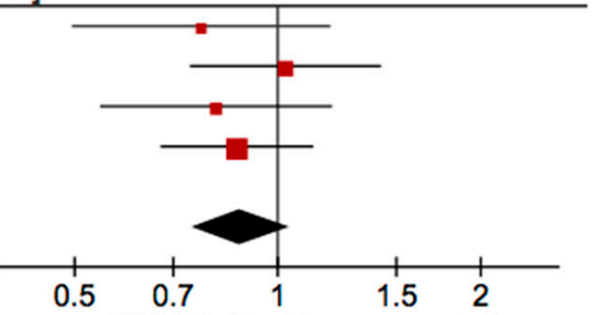

Favours anti-HER3 Ab Favours control

B

\begin{tabular}{|c|c|c|c|c|}
\hline Study or Subgroup & Weight & Hazard Ratio $[95 \% \mathrm{Cl}]$ & & \\
\hline Higgins 2014 & $12.3 \%$ & $0.31[0.10,0.98]$ & $-\pi$ & \\
\hline Liu 2014 & $27.4 \%$ & $0.37[0.17,0.80]$ & $\rightarrow-$ & \\
\hline Sequist 2014 & $29.2 \%$ & $0.38[0.18,0.80]$ & $=-$ & \\
\hline Von Pawel 2014 & $31.1 \%$ & $0.32[0.15,0.66]$ & & \\
\hline Total & $100.0 \%$ & $0.35[0.23,0.52]$ & & \\
\hline Heterogeneity: $P=0.98 ; 1^{2}=0 \%$ & & 0.01 & 0.1 & 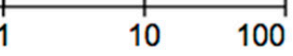 \\
\hline Test for overall effect: $P<0.001$ & & Favours & ti-HER3 Ab & Favours control \\
\hline
\end{tabular}

Figure 4: Forest plots showing effect of anti-HER3 antibodies on progression-free survival among unselected patients (A), or patients with NRG expression (B). 
Table 3: Pooled analyses of toxicities from anti-HER3 antibodies

\begin{tabular}{|l|c|c|c|}
\hline \multicolumn{1}{c|}{ Toxicity } & Pooled OR & $\mathbf{9 5 \%}$ CI & $\boldsymbol{p}$ \\
\hline Diarrhea & 3.06 & $2.21-4.25$ & $<0.001$ \\
\hline Nausea and vomiting & 1.81 & $1.21-2.70$ & 0.004 \\
\hline Rash & 1.81 & $1.24-2.65$ & 0.002 \\
\hline
\end{tabular}

\section{Data extraction}

Two reviewers (LD, AO) evaluated independently all the titles identified by the search strategy. The results were then pooled and all potentially relevant publications retrieved in full and assessed for eligibility. Disagreement was resolved by consensus.

The following information was captured using data abstraction forms: Name of first author, year of publication, type of tumor, NRG studied, methods used for the evaluation of NRG, proportion of patients with $\mathrm{NRG}$ expression and the number of patients treated with anti-HER3 therapies. Survival data were estimated from multivariable analyses independently by two authors (EA, LD) and disagreement was resolved by consensus.

If HRs were not reported we extracted the odds of survival at three and five years from Kaplan-Meier curves and calculated odds ratios (OR) with 95\% CI. For studies reporting both HR and Kaplan-Meier curves, we preferentially used the multivariable HR. Finally, we extracted data of the most commonly reported toxicities and calculated OR with $95 \%$ CI for these toxicities, comparing anti-HER3 therapies to placebo.

\section{Data synthesis and statistical analyses}

Study characteristics were reported descriptively using means and proportions. Studies reporting HR for OS or PFS were weighted and pooled using the generic inverse variance and random-effect model [48]. Studies reporting the odds of death or progression at 3 or 5 years or the odds of commonly reported toxicities were weighted and pooled using the Mantel-Haenszel randomeffect model. All meta-analyses were conducted using RevMan 5.3 analysis software (Cochrane Collaboration, Copenhagen, Denmark).

Statistical heterogeneity was assessed using the Cochran's Q and $I^{2}$ statistics. Subgroup analyses were conducted as described by Deeks et al. [49]. All statistical tests were two-sided, and statistical significance was defined as $p<0.05$. No corrections were made for multiple testing.

\section{ACKNOWLEDGMENTS AND FUNDING}

Instituto de Salud Carlos III (PI13/01444), ACEPAIN; Diputación de Albacete and CRIS Foundation (to AO). Ministry of Economy and Competitiveness of Spain (BFU2012-39151), the Instituto de Salud Carlos III through the Spanish Cancer Centers Network Program (RD12/0036/0003), the scientific foundation of the AECC and the CRIS Foundation (to AP). Instituto de Salud Carlos III (PI15/01180) (to AE-O). JCM is a recipient of a Miguel Servet fellowship program (CP12/03073). The work carried out in the EU laboratories receive support from the European Community through the regional development funding program (FEDER).

\section{CONFLICTS OF INTEREST}

No authors have any competing interests. An ethics statement was not required for this work. No funding was received for this work.

\section{REFERENCES}

1. Montero JC, Rodriguez-Barrueco R, Ocana A, DiazRodriguez E, Esparis-Ogando A, Pandiella A. Neuregulins and Cancer. Clin Cancer Res. 2008; 14:3237-3241.

2. Holmes WE, Sliwkowski MX, Akita RW, Henzel WJ, Lee J, Park JW, Yansura D, Abadi N, Raab H, Lewis GD, Shepard HM, Kuang WJ, Wood WI, et al. Identification of heregulin, a specific activator of p185erbB2. Science. 1992; 256:1205-1210.

3. Carraway KL, 3rd, Weber JL, Unger MJ, Ledesma J, Yu N, Gassmann M, Lai C. Neuregulin-2, a new ligand of ErbB3/ ErbB4-receptor tyrosine kinases. Nature. 1997; 387:512-516.

4. Hynes NE, Lane HA. ERBB receptors and cancer: the complexity of targeted inhibitors. Nat Rev Cancer. 2005; 5:341-354

5. Holbro T, Civenni G, Hynes NE. The ErbB receptors and their role in cancer progression. Exp Cell Res. 2003; 284:99-110.

6. Baselga J, Swain SM. Novel anticancer targets: revisiting ERBB2 and discovering ERBB3. Nat Rev Cancer. 2009; 9:463-475.

7. Carraway KL, 3rd, Sliwkowski MX, Akita R, Platko JV, Guy PM, Nuijens A, Diamonti AJ, Vandlen RL, Cantley LC, Cerione RA. The erbB3 gene product is a receptor for heregulin. J Biol Chem. 1994; 269:14303-14306.

8. Ocana A, Pandiella A. Identifying breast cancer druggable oncogenic alterations: leasons learned and future options. Clin Cancer Res. 2008; 14:961-970. 
9. Ocana A, Vera-Badillo F, Seruga B, Templeton A, Pandiella A, Amir E. HER3 overexpression and survival in solid tumors: a meta-analysis. J Natl Cancer Inst. 2013; 105:266-273.

10. Meetze K, Vincent S, Tyler S, Mazsa EK, Delpero AR, Bottega S, McIntosh D, Nicoletti R, Winston WM, Weiler S, Feng B, Gyuris J, Weng Z. Neuregulin 1 expression is a predictive biomarker for response to AV-203, an ERBB3 inhibitory antibody, in human tumor models. Clin Cancer Res. 2015; 21:1106-1114.

11. Sliwkowski MX, Schaefer G, Akita RW, Lofgren JA, Fitzpatrick VD, Nuijens A, Fendly BM, Cerione RA, Vandlen RL, Carraway KL 3rd. Coexpression of erbB2 and erbB3 proteins reconstitutes a high affinity receptor for heregulin. J Biol Chem. 1994; 269:14661-14665.

12. Forster JA, Paul AB, Harnden P, Knowles MA. Expression of NRG1 and its receptors in human bladder cancer. Br J Cancer. 2011; 104:1135-1143.

13. Amsellem-Ouazana D, Bieche I, Tozlu S, Botto H, Debre B, Lidereau R. Gene expression profiling of ERBB receptors and ligands in human transitional cell carcinoma of the bladder. J Urol. 2006; 175:1127-1132.

14. Memon AA, Sorensen BS, Melgard P, Fokdal L, Thykjaer T, Nexo E. Expression of HER3, HER4 and their ligand heregulin-4 is associated with better survival in bladder cancer patients. Br J Cancer. 2004; 91:2034-2041.

15. Seoane S, Montero JC, Ocana A, Pandiella A. Breast cancer dissemination promoted by a neuregulin-collagenase 3 signalling node. Oncogene. 2015 Sep 14; doi: 10.1038/ onc.2015.337.

16. Haas S, Gevensleben H, Rabstein S, Harth V, Pesch B, Bruning T, Justenhoven C, Brauch H, Hamann U, Ko YD, Baisch C, Fischer HP, Buttner R. Expression of heregulin, phosphorylated HER-2, HER-3 and HER-4 in HER-2 negative breast cancers. Oncol Rep. 2009; 21:299-304.

17. de Alava E, Ocana A, Abad M, Montero JC, EsparisOgando A, Rodriguez CA, Otero AP, Hernandez T, Cruz JJ, Pandiella A. Neuregulin expression modulates clinical response to trastuzumab in patients with metastatic breast cancer. J Clin Oncol. 2007; 25:2656-2663.

18. Marshall C, Blackburn E, Clark M, Humphreys S, Gullick WJ. Neuregulins 1-4 are expressed in the cytoplasm or nuclei of ductal carcinoma (in situ) of the human breast. Breast Cancer Res Treat. 2006; 96:163-168.

19. Dunn M, Sinha P, Campbell R, Blackburn E, Levinson N, Rampaul R, Bates T, Humphreys S, Gullick WJ. Co-expression of neuregulins 1, 2, 3 and 4 in human breast cancer. J Pathol. 2004; 203:672-680.

20. Raj EH, Skinner A, Mahji U, Nirmala KN, Ravichandran K, Shanta V, Hurst HC, Gullick WJ, Rajkumar T. Neuregulin 1-alpha expression in locally advanced breast cancer. Breast. 2001; 10:41-45.

21. Esteva FJ, Hortobagyi GN, Sahin AA, Smith TL, Chin DM, Liang SY, Pusztai L, Buzdar AU, Bacus SS. Expression of erbB/HER receptors, heregulin and $\mathrm{P} 38$ in primary breast cancer using quantitative immunohistochemistry. Pathol Oncol Res. 2001; 7:171-177.

22. Visscher DW, Sarkar FH, Kasunic TC, Reddy KB. Clinicopathologic analysis of amphiregulin and heregulin immunostaining in breast neoplasia. Breast Cancer Res Treat. 1997; 45:75-80.

23. Normanno $\mathrm{N}$, Kim $\mathrm{N}$, Wen $\mathrm{D}$, Smith $\mathrm{K}$, Harris AL, Plowman G, Colletta G, Ciardiello F, Salomon DS. Expression of messenger RNA for amphiregulin, heregulin, and cripto-1, three new members of the epidermal growth factor family, in human breast carcinomas. Breast Cancer Res Treat. 1995; 35:293-297.

24. Mitsui K, Yonezawa M, Tatsuguchi A, Shinji S, Gudis K, Tanaka S, Fujimori S, Sakamoto C. Localization of phosphorylated ErbB1-4 and heregulin in colorectal cancer. BMC Cancer. 2014; 14:863.

25. De Boeck A, Pauwels $\mathrm{P}$, Hensen K, Rummens JL, Westbroek W, Hendrix A, Maynard D, Denys H, Lambein K, Braems G, Gespach C, Bracke M, De Wever O. Bone marrow-derived mesenchymal stem cells promote colorectal cancer progression through paracrine neuregulin 1/HER3 signalling. Gut. 2013; 62:550-560.

26. Venkateswarlu S, Dawson DM, St Clair P, Gupta A, Willson JK, Brattain MG. Autocrine heregulin generates growth factor independence and blocks apoptosis in colon cancer cells. Oncogene. 2002; 21:78-86.

27. Srinivasan R, Benton E, McCormick F, Thomas H, Gullick WJ. Expression of the c-erbB-3/HER-3 and c-erbB-4/HER-4 growth factor receptors and their ligands, neuregulin-1 alpha, neuregulin-1 beta, and betacellulin, in normal endometrium and endometrial cancer. Clin Cancer Res. 1999; 5:2877-2883.

28. Ebi M, Kataoka H, Shimura T, Hirata Y, Mizushima T, Mizoshita T, Tanaka M, Tsukamoto H, Ozeki K, Tanida S, Kamiya T, Inagaki H, Joh T. The role of neuregulin4 and HER4 in gastrointestinal malignant lymphoma. Mol Med Rep. 2011; 4:1151-1155.

29. Hsieh SY, He JR, Hsu CY, Chen WJ, Bera R, Lin KY, Shih TC, Yu MC, Lin YJ, Chang CJ, Weng WH, Huang SF. Neuregulin/erythroblastic leukemia viral oncogene homolog 3 autocrine loop contributes to invasion and early recurrence of human hepatoma. Hepatology. 2011; 53:504-516.

30. Pan B, Wang R, Huang Y, Garfield D, Zhang J, Chen H. $\mathrm{HGF}$ and NRG1 protein expression are not poor prognostic markers in surgically resected lung adenocarcinoma. OncoTargets Ther. 2015; 8:1185-1191.

31. Gilbertson RJ, Clifford SC, MacMeekin W, Meekin W, Wright C, Perry RH, Kelly P, Pearson AD, Lunec J. Expression of the ErbB-neuregulin signaling network during human cerebellar development: implications for the biology of medulloblastoma. Cancer Res. 1998; 58:3932-3941.

32. Qian G, Jiang N, Wang D, Newman S, Kim S, Chen Z, Garcia G, MacBeath G, Shin DM, Khuri FR, Chen ZG, Saba NF. Heregulin and HER3 are prognostic biomarkers 
in oropharyngeal squamous cell carcinoma. Cancer. 2015; 121:3600-3611.

33. Gilmour LM, Macleod KG, McCaig A, Sewell JM, Gullick WJ, Smyth JF, Langdon SP. Neuregulin expression, function, and signaling in human ovarian cancer cells. Clin Cancer Res. 2002; 8:3933-3942.

34. Kolb A, Kleeff J, Arnold N, Giese NA, Giese T, Korc M, Friess H. Expression and differential signaling of heregulins in pancreatic cancer cells. Int J Cancer. 2007; 120:514-523.

35. Fluge O, Akslen LA, Haugen DR, Varhaug JE, Lillehaug JR. Expression of heregulins and associations with the ErbB family of tyrosine kinase receptors in papillary thyroid carcinomas. Int J Cancer. 2000; 87:763-770.

36. Hayes NV, Blackburn E, Boyle MM, Russell GA, Frost TM, Morgan BJ, Gullick WJ. Expression of neuregulin 4 splice variants in normal human tissues and prostate cancer and their effects on cell motility. Endocr-Relat Cancer. 2011; 18:39-49.

37. Grimsley SJ, Shini S, Underwood MA, Edwards J. Heregulin expression and prognosis in prostate adenocarcinoma. Urol Int. 2011; 87:363-368.

38. Lyne JC, Melhem MF, Finley GG, Wen D, Liu N, Deng DH, Salup R. Tissue expression of neu differentiation factor/ heregulin and its receptor complex in prostate cancer and its biologic effects on prostate cancer cells in vitro. Cancer J Sci Am. 1997; 3:21-30.

39. Leung HY, Weston J, Gullick WJ, Williams G. A potential autocrine loop between heregulin-alpha and erbB-3 receptor in human prostatic adenocarcinoma. Br J Urol. 1997; 79:212-216.

40. Hansen MR, Linthicum FH, Jr. Expression of neuregulin and activation of erbB receptors in vestibular schwannomas: possible autocrine loop stimulation. Otol Neurotol. 2004; 25:155-159.

41. Higgins MJ, Doyle C, Paepke S, Azaro A, Martin M, Semiglazov V, Smirnova I, Krasnozhon D, Manikhas A, Harb WA, Panasci LC, Pearlberg J, MacBeath G, et al. A randomized, double-blind phase II trial of exemestane plus MM-121 (a monoclonal antibody targeting ErbB3) or placebo in postmenopausal women with locally advanced or metastatic $\mathrm{ER}+/ \mathrm{PR}+$, HER2-negative breast cancer. J Clin Oncol. 2014; 32: ASCO Annual Meeting Abstracts (suppl; abstr 587).
42. Liu J, Ray-Coquard IL, Selle F, Poveda A, Cibula D, Hirte HW, Raspagliesi F, Gladieff L, Harter P, Schiavetto I, Tabah-Fisch IM, MacBeath G, Czibere AG, et al. A Phase 2 Randomized Open Label Study of MM-121, a Fully Human Monoclonal Antibody Targeting ErbB3, in Combination with Weekly Paclitaxel, Versus Weekly Paclitaxel Alone, in Patients with Platinum Resistant/Refractory Ovarian Cancers. J Clin Oncol. 2014; 32: ASCO Annual Meeting Abstracts (suppl; abstr 5519).

43. Sequist LV, Lopez-Chavez A, Doebele RC, Gray JE, Harb WA, Modiano MR, Jackman DM, Baggstrom MQ, Atmaca A, Felip E, Provencio M, Cobo M, Kripas CJ, et al. A randomized phase 2 trial of MM-121, a fully human monoclonal antibody targeting ErbB3, in combination with erlotinib in EGFR wild-type NSCLC patients. J Clin Oncol. 2014; 32: ASCO Annual Meeting Abstracts (suppl; abstr 8051).

44. Von Pawel J, Tseng J, Dediu M, Schumann C, Moritz B, Mendell-Harary J, Jin X, Feng W, Copigneaux C, Beckman RA. Phase 2 HERALD study of patritumab (P) with erlotinib (E) in advanced NSCLC subjects. J Clin Oncol. 2014; 32: ASCO Annual Meeting Abstracts (suppl; abstr 8051).

45. Yuste L, Montero JC, Esparis-Ogando A, Pandiella A. Activation of ErbB2 by overexpression or by transmembrane neuregulin results in differential signaling and sensitivity to herceptin. Cancer Res. 2005; 65:6801-6810.

46. Yap TA, Gerlinger M, Futreal PA, Pusztai L, Swanton C. Intratumor heterogeneity: seeing the wood for the trees. Sci Transl Med. 2012; 4:127ps10.

47. Moher D, Liberati A, Tetzlaff J, Altman DG. Preferred reporting items for systematic reviews and meta-analyses: the PRISMA statement. PLoS Med. 2009; 6:e1000097.

48. DerSimonian R, Laird N. Meta-analysis in clinical trials. Control Clin Trials. 1986;7:177-188.

49. Deeks JJ, Higgins, JPT, Altman DG, editors. Analysing and presenting results. In: Higgins JPT, Green S, editors. Cochrane Handbook for Systematic Reviews of Interventions 4.2.6 [updated September 2006]; Section 8. In: The Cochrane Library, Issue 4, 2006. Chichester, UK: John Wiley \& Sons, Ltd. 